\title{
Minutes of the Assembly of the Brazilian Crustacean Society
}

Harry Boos, Liliam Hayd and Sergio Schwarz da Rocha

(HB) Secretário da Sociedade Brasileira de Carcinologia; Centro Nacional de Pesquisa e Conservação da Biodiversidade Marinha do Sudeste e Sul (CEPSUL), Instituto Chico Mendes de Conservação da Biodiversidade (ICMBio), Ministério do Meio Ambiente (MMA). Av. Ministro Victor Konder, 374, 88301-700, Itajaí, Santa Catarina, Brazil. E-mail: harry.boos-junior@icmbio.gov.br.

(LH) Presidente do VIII CBC; Universidade Estadual de Mato Grosso do Sul, Campus de Aquidauana. Rodovia Aquidauana UEMS Km 12. 79200-000, Aquidauana, Mato Grosso do Sul, Brazil. E-mail: lilihayd@gmail.com.

(SSR) Presidente da Sociedade Brasileira de Carcinologia; Universidade Federal do Recôncavo da Bahia (UFRB), Centro de Ciências Agrárias, Ambientais e Biológicas (CCAAB), Campus Universitário. Rua Rui Barbosa, 710, Bairro Centro. 44380-000, Cruz das Almas, Bahia, Brazil. E-mail: presidente@crustacea. org.br.

On 11 November 2014, during the VIII Brazilian Crustacean Congress, held at Bonito, Mato Grosso do Sul (see below), an assembly was held of all the members of the SBC who were present. To save time, the President, Dr. Sergio Schwarz da Rocha, proposed that the Minutes of the previous meeting (Minutes No. 17) be made available on the SBC website. A similar procedure will be adopted for the Minutes of this meeting. The assembly also formally recognized the list of new members accepted by the Board in the 2013-2014 biennium.

The President reported on all administrative actions taken by the Directorate during the 20132014 period, and the Treasurer, Dr. Cléverson Ranniéri Meira dos Santos, reported on the current account balance, legal expenses, and the current financial situation of the SBC. The Counselor, Dr. Marcelo Antonio Amaro Pinheiro, read the Council's opinion on the administrative actions and the financial report of the current Directorate, in which both reports were approved. Finally, the assembly voted unanimously in favor of the Council's opinion on these matters.

The Editor of Nauplius, Dr. Fernando Luis Medina Mantelatto, reported on the present situation of the journal, highlighting the statistics on visits to the journal's website and pointed out some editorial actions that could improve the manuscript submission process. Last, Dr. Mantelatto informed the members of the expiration of his term as Editor and announced that Dr. Paula Beatriz de Araujo will serve as editor-in-chief, and Dr. Alexandre Oliveira de Almeida as assistant editor for the 2015-2019 period. The Assembly, as a sign of our appreciation and gratitude, applauded both the retiring and the new editors.

Before the election of the new Directorate and Council for the 2015-2016 biennium, the current President and candidate for re-election, Dr. Sergio Schwarz da Rocha, detailed his guidelines and goals for the next biennium. After that, Dr. Alessandra Angélica de Pádua Bueno, President of the Electoral Commission, explained the voting process and conducted the balloting.

The new Directorate was elected:

- President: Sergio Schwarz da Rocha (UFRB)

- Vice-President: Harry Boos Junior (CEPSUL/ICMBio)

- Secretary (1): Luis Ernesto Arruda Bezerra (UFERSA)

- Secretary (2): William Ricardo Amancio Santana (USC)

- Treasurer (1): Cleverson Ranniéri Meira dos Santos (Museu Goeldi)

- Treasurer (2): Ricardo Lourenço Pinto (UNB)

Councilors: Marcelo Antonio Amaro Pinheiro (UNESP), Carlos Eduardo Falavigna da Rocha (USP) and Cristiana Silveira Serejo (MNRJ).

The assembly voted in favor of holding the IX CBC in Crato, Ceará, during a period to be determined by the local committee, composed 
by Dr. Allysson Pontes Pinheiro (Universidade Regional do Cariri) (Cariri Regional University), during the year 2016. In conclusion, Dr. Alexandre Oliveira de Almeida expressed his desire to organize the X CBC in Recife or Porto de Galinhas, Pernambuco, in 2018. There being no further business, the meeting was adjourned by the President.

\section{ViII Brazilian Crustacean Congress}

The VIII Brazilian Crustacean Congress (VIII $\mathrm{CBC})$, was held at the Bonito Convention Center, in Bonito, Mato Grosso do Sul, November 9-12/2014. The event was distinguished by the richness of its scientific quality and included a keynote speech, three conferences, five symposia, two workshops, eighteen oral presentation sessions and two panel presentation sessions, as well as 337 abstracts published in the Annals of the Event (http://www.crustacea.org.br/? $\mathrm{p}=1484 /$ \&lang=pt). Altogether, 314 carcinologists from eighteen Brazilian states and six other countries (Argentina, Australia, Bolivia, Portugal, Germany and Mexico) took part.

Several renowned carcinologists were present at the VIII CBC, which certainly added luster to the congress. Dr. Klaus Anger (Alfred Wegener Institute, Germany), Dr. Christoph Schubart (University of Regensburg, Germany), Dr. Ricardo Calado (University of Aveiro, Portugal), Dr. Sergio Luiz de Siqueira Bueno (Universidade de São Paulo, Instituto de Biociências), Dr. Wagner Cotroni Valenti (Universidade Estadual Paulista, Campus do Litoral Paulista), Dr. Paula Beatriz de Araujo (Universidade Federal do Rio Grande do Sul, Instituto de Biociências), Dr. Cristiana Silveira
Serejo (Universidade Federal do Rio de Janeiro, Museu Nacional do Rio de Janeiro), Dr. Marcelo Antonio Amaro Pinheiro (Universidade Estadual Paulista, Campus do Litoral Paulista), Dr. Marcos Domingos Siqueira Tavares (Universidade de São Paulo, Museu de Zoologia), and Dr. Fernando Luis Medina Mantelatto (Universidade de São Paulo, Faculdade de Filosofia Ciências e Letras de Ribeirão Preto) are some of the researchers who contributed presentations.

The Brazilian Crustacean Society (SBC) awarded prizes for the best student presentations in the oral and poster sessions. We congratulate the two graduate student recipients: Helena de Oliveira Souza (Universidade Federal do Rio de Janeiro) for her oral presentation "Tolerância de Quadrivisio aff. lutzi (Amphipoda) a diferentes salinidades e temperaturas" and Juliana Cristina Bertacini Moraes (Universidade de São Paulo) for her poster presentation "Morfologia externa dos tubos sexuais em espécies do gênero Aegla (Decapoda, Anomura, Aeglidae)"; and the two undergraduate recipients: Isabela Ribeiro Rocha de Moraes (Universidade de Taubaté) for her oral presentation "Preferência alimentar do camarão ornamental Hymenocera picta (Decapoda, Caridea, Hymenoceridae) em condiçóes de laboratório" and Silvia Sayuri Mandai (Universidade de São Paulo, Faculdade de Filosofia Ciências e Letras de Ribeirão Preto) for her poster presentation "Variabilidade populacional do ermitão Calcinus tibicen (Anomura: Diogenidae): Atlântico Norte versus Brasil”.

In addition to the meeting, a spectacular demonstration of typical Pantanal music, performed by the guitarist Marcelo Loureiro and the singer Jane Ribeiro, as well as the traditional costume party entertained the participants. 